\title{
Physical therapy evaluation and treatment in distal radius fracture: a case report
}

\author{
Maylli Daiani Graciosa', Tamiris Beppler Martins', Keyla Mara dos Santos', Juliete Palandi', Larissa Sinhorim¹, \\ Gilmar Moraes Santos ${ }^{1}$
}

\begin{abstract}
Introduction: subjects who have suffered DRF submitted immobilization may have a loss in active range of motion and functional deficit. Objectives: evaluate changes in the wrist and verify the effectiveness of physical therapy intervention used in the treatment of DRF. Methods: a physiotherapy evaluation form, goniometry and Visual Analogue Scale were used to assess the patient. A treatment protocol was applied for seven sessions. Results: the results showed reduced pain and increased range of motion of the wrist. Conclusion: there were changes as pain and reduced range of motion of the wrist. The treatment protocol was effective for these changes.
\end{abstract}

Key words: Radius Fractures. Physical Therapy. Rehabilitation.

\section{INTRODUCTION}

The falls are considered unintentional events ${ }^{(1)}$ which generally produce restriction in daily activities of individuals ${ }^{(2)}$ and in most cases, may result in physical injuries such as fractures. ${ }^{(3)}$ In addition, the prevalence of falls among women $(33 \%)$ is higher than in males $(22.3 \%) .{ }^{(4,5)}$

Among the fractures occurred, there are the Distal Radio Fractures (DRF), found often in emergency services, ${ }^{(6)}$ usually associated with falling on hand in hyperextension. ${ }^{(7)}$ It is known that one of the widely used methods for the treatment of fractures is the immobilization. ${ }^{(8)}$ However, changes in properties of connective and muscle tissues may occur due to the absence of stress on them. ${ }^{(9)}$

Thus, in addition to complications from the injury, ${ }^{(10)}$ individuals may also have deleterious effects arising from the immobilization process. Studies show that this method of treatment may cause changes in the first week. ${ }^{(11,12)}$ Among these consequences include the increased density of intramuscular connective tissue ${ }^{(12)}$ and muscle atrophy. ${ }^{(11)}$

Thus, individuals who suffered fractures and are subjected to immobilization may have joint stiffness and reduced muscle strength. These factors contribute to a loss in active range of motion, and consequent functional deficit. In these cases, the physiotherapy intervention is considered of great importance, since it may work in the rehabilitation of DRF in order to not only prevent such complications, ${ }^{(8)}$ but also recover the function of the patient. ${ }^{(6)}$
The physiotherapy intervention in cases of DRF has been investigated by several studies. ${ }^{(13,14,15,16)}$ During the phase of post-immobilization, are considered as the most frequent therapeutic procedures the application of heat and cold, joint mobilizations, range of motion exercises, stretching, strengthening and manual dexterity. ${ }^{(16)}$ From the reduction of pain and range of motion gain, physical therapy may benefit the member function from 20 therapy sessions. ${ }^{(13)}$

Although some studies show positive effects of physiotherapy in patients with DRF, literature meant that therapeutic strategies prepared based on general principles of rehabilitation, which are not well documented, difficult to evidence-based practice by professionals who treat this pathology. ${ }^{(6)}$

Thus, it is considered important to continue the search for evidence concerning the appropriate therapeutic approaches for rehabilitation after DRF. It is believed that the associations between the techniques already studied with different approaches may bring new information about the processing time required to generate positive effect of the conduct. It is believed that the inclusion of manual therapy techniques for treating the DRF may reduce the time to reduce the pain symptoms and to gain range of motion, thus enabling a quicker return of the patient to its activities of daily living.

Based on the above, this study aims to evaluate the changes in the wrist of a DRF case and verify the effectiveness of physiotherapy intervention used in the treatment. 


\section{METHODS}

\section{Study}

This is a case report characterized as a descriptive and longitudinal study with purposive sample.

\section{Local and research period}

This study was conducted at the Clinical School of Physiotherapy at the University of the State of Santa Catarina - UDESC in Florianópolis. Both evaluation or physiotherapy intervention were carried out from March 10 to April 9, 2014.

\section{Study Tools}

The instrument used was a Physiotherapy Assessment Form, the Visual Analogue Scale (VAS) and goniometer.

The physiotherapy assessment form was developed by the teachers responsible for Orthopedics discipline UDESC. This worksheet contained identification data, clinical history, physical examination, objectives and behaviors.

It was used the VAS to measure the level of pain in the wrist of the patient. This scale is graduated in ten levels, where zero is no pain and ten is the worst possible pain. Therefore, the pain is classified in three levels: mild (zero to two), moderate (three to seven) and severe (eight to ten).

The goniometry was carried out using a goniometer, in order to evaluate the angulation range of active movement in the wrist: flexion, hyperextension, deviation ulnar and radial. The measurements were performed according to Marques. ${ }^{(17)}$

The VAS was applied during the evaluation and weekly during each intervention. The goniometry was used in the evaluation and reassessment date.

\section{Case report}

Female patient, 57 years old, with a clinical diagnosis of left Radio Distal fracture after falling from her height, the date of November 16, 2013. He was treated with immobilization by plaster during two months after the injury. After removal of the plaster, it was made continuous use of orthopedic splint until the valuation date. She was referred to UDESC physiotherapy service at the date of March 10, 2014. No others physiotherapeutic interventions were made prior to the valuation date.

\section{Procedures}

The study was approved by the Ethics of the State University of Santa Catarina Committee (UDESC), number 789,272.

The subject was informed about the study and then signed a free and informed consent.

Seven physiotherapeutic sessions were held for four weeks, twice a week, during 40 minutes. The patient did not attend the treatment in the second week. The intervention and physiotherapeutic evaluation were performed by a single therapist. The established treatment plan aimed to: reduce pain and gain left wrist range of motion for flexion, hyperextension, ulnar and radial deviation.

To meet these objectives, the treatment protocol consisted of manual therapy, intra-articular mobilization exercises and kinesiotherapy exercises associated with thermotherapy. Thus, it was obtained the following sequence:

a) Technical myofascial release: kneading, deep landslides and fascial traits in wrist flexors and extensors muscles and palmar aponeurosis.

b) manual traction passive exercise: in radio carpal and humerus-radial joints. ${ }^{(18)}$ Three replicates were made for 30 seconds.

c) intra-articular mobilization: slips (radio ulnar distal, proximal carpal radio and humerus-radial joints). The mobilizations were initially made in the grade I and as the pain decrease it was made in grade II and III. ${ }^{(18)}$ Two series were made of 20 oscillations.

d) thermotherapy application associated with range of motion exercises for the wrist: wrist passive and active exercises (flexion, hyperextension, radial and ulnar deviation) in the whirlwind. Initially two sets of ten repetitions were done. With the reduction of pain, it was changed to three sets of 15 repetitions. These procedures were performed according to Kisner and Colby. ${ }^{(19)}$

e) passive stretching for flexors and extensors muscles of the wrist. The stretches were conducted in two series of one minute each muscle. Stretches performed as Kisner and Colby. ${ }^{(19)}$

\section{Data analysis}

To analyze the results of the VAS, an arithmetic mean was made among the results of each day of the week. Thus, each week of treatment showed one value for the level of pain.

\section{RESULTS}

The results, concerning the evolution of the wrist movements of flexion, extension and ulnar and radial deviation, according to the goniometry are shown in Table 1.

Figure 1 shows the VAS results at each week intervention. Regarding the results of pain, the patient on the valuation date, pain in the left wrist with VAS $=7$. At the end of treatment, in revaluation, the patient presented VAS $=0$.

Through evaluation form it was obtained the functional kinesio diagnosis: range of motion reduction in left wrist. It was also observed the main complaint of the patient which was the presence of pain in the left wrist at resting and during passive and active movement. 
Table 1: Goniometry pre- and post-physiotherapeutic intervention for active range of motion of the wrist.

\begin{tabular}{lcccccc}
\hline \multirow{2}{*}{ Movements } & \multicolumn{2}{c}{ PRE } & & \multicolumn{2}{c}{ POST } \\
\cline { 2 - 3 } \cline { 5 - 6 } & Right & Left & & Right & Left \\
\hline Flexion (degrees) & 50 & 5 & & 50 & 51 \\
Hyperextension (degrees) & 40 & 20 & & 49 & 55 \\
Radial deviation (degrees) & 20 & 10 & & 20 & 20 \\
Ulnar deviation (degrees) & 30 & 20 & & 33 & 38 \\
\hline
\end{tabular}

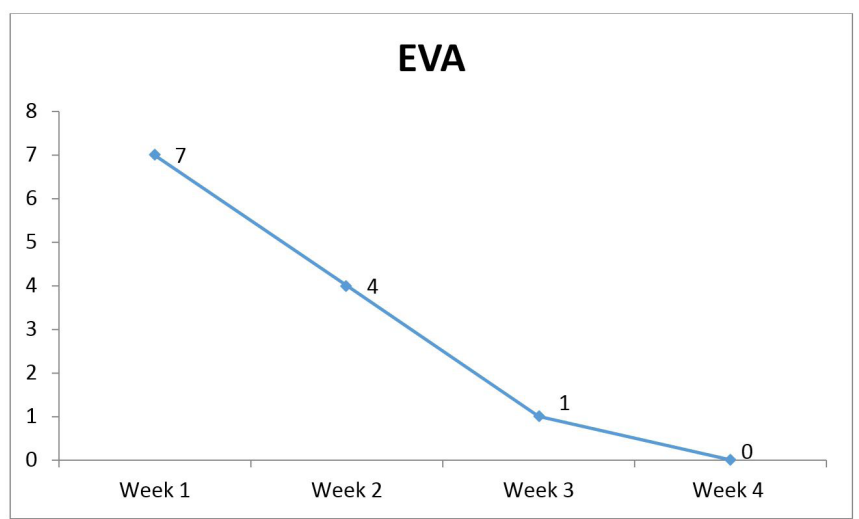

Figure 1: Pain Scale (left wrist) measured in the first, second, third and fourth weeks of physiotherapy intervention.

\section{DISCUSSION}

The Distal Radio Fractures (DRF) may bring numerous complications for the individuals who suffered. (10) The physiotherapy intervention is considered relevant for the rehabilitation process. ${ }^{(13)}$ The aim of this study was to evaluate a case of distal radius fracture (DRF) after fall, and verify the main physical changes. Furthermore, it was also verified the effect of physiotherapeutic treatment plan in these disorders.

It was observed through physiotherapy evaluation that the main changed aspect was the range of motion, and that the main complaint of the patient was associated with the presence of pain. With the proposed treatment protocol, it was found as a result, active range of motion gain for the wrist as well as reduction in pain levels until its absence.

Regarding pain, on the valuation date, the patient reported severe pain. Almeida, Tsai and Costa, ${ }^{(13)}$ also found in their study, the pain as a major complication of DRF. This factor may be explained based on the method of treatment used in this case, which was the use of plaster for two months after the date of injury. Yeng, Kaziyama and Teixeira(20) ${ }^{(20 t e}$ that the stillness may be one of the triggers of pain. The authors state that the pain may be related to a muscular deficiency arising from flexibility to movement loss. ${ }^{(20)}$

In the initial evaluation of the goniometer for all analyzed movements, it was found smaller angles to the left wrist with respect to the right wrist. These results support the Almeida study findings (2014). In the study by Engles (1994) it was found that the absence process of movement caused by immobility may result loss in basic components of the tissue, and have a negative impact on their function. Thus, a greater joint limitation caused by stiffness, will require greater strength of the individual to move the fixed segment in its range of appropriate movement. (21)

The treatment plan implemented for this case obtained effect with respect to pain relief, which went from intense (first evaluation) to absent (last evaluation). During the weeks of intervention, there was a reduction in pain gradually and progressively. In the first week, the patient still had severe pain. In the second, the pain appeared as moderate. In the third as mild. And in the fourth week the pain already nonexistent.

Other studies have also found decreased levels of pain through therapeutic exercises in the intervention of the DRF. ${ }^{(13,14,15)}$ It was observed the positive effect of manual therapy in several types of pain. ${ }^{(22.23)}$ Thus, the results regarding pain in this study may be associated with both kinesiotherapy exercises performed, but also manual therapy techniques. Still, such gains may result from the exercises performed in the whirlwind through thermotherapy, since its physiological effects include analgesia. (24)

The final evaluation of the active range of motion showed through the goniometer, that all assessed angles increased with respect to baseline (data for the left wrist). Besides increasing, all angles were similar to the unaffected wrist. Almeida, Tsai and Costa, ${ }^{(13)}$ also observed such results after making their treatment protocol. It is noteworthy that the protocol performed by these authors took place in 20 sessions and also included strengthening exercises, while in this study occurred only seven sessions and strength exercises have not been proposed.

It is noteworthy that the protocol conducted by the authors occurred in 20 sessions and included strengthening exercises and stretching. However, the present study found the same results from seven sessions. In this sense, the studied protocol showed quick results with respect to the gain range of motion and reporting of pain. When comparing the subjects assessed by two studies, it is observed that both are female and are presented in the same age group. For both protocols, sessions occurred twice a week with similar periods of time.

The differences among the results of the two studies may be justified based on defaulted conduct. Among these the one which showed similarity between the two protocols were stretching exercises. However, in this study utilized it was used stretching exercises and maintained for at least one minute per muscle group, while Almeida, Tsai and Costa(13) opted for active stretches that were held between five and 15 seconds. Active stretching exercise has been considered in the literature as the most effective in relation to passive. ${ }^{(25)}$ Thus, it is suggested that the time kept during stretching may have influenced these results, since the minimum time of 30 seconds is considered ideal. ${ }^{(26)}$ 
In this sense, the study protocol showed quick results with respect to the range of motion gain. One factor which may have influenced the improvement, is due to manual therapy promote plasticity of fascial tissue through the reorganization of collagen fibers, thus enabling an increase in the length of the body tissues. ${ }^{(27)}$

And, by explaining the increased range of motion, the use of the whirlwind provided to increase the metabolism and local circulation, and thereby promoting the extensibility of soft tissue, muscle relaxation and a decrease in joint stiffness. ${ }^{(28)}$

In addition to the range of motion gain be associated with thermotherapy, it is known that therapeutical exercises, and intra-articular mobilizations were crucial to this development. Such techniques reduce the stiffness because they stimulate the production of synovial fluid in the joints. Also avoid the reduction of sarcomeres in series and deposition of intramuscular fat, preventing the shortening and reduced muscle strength. ${ }^{(28)}$

The main changes observed in this case DRF probably are related to prolonged immobilization period in the treatment of the patient. This fact shows the necessity for the physiotherapist to pay attention to the undesirable effects of immobilization, to prevent further damage during treatment. ${ }^{(28)}$

It is known that the tissues adapt the loads imposed on them, and the absence of load may cause tissue injury ${ }^{(9)}$ bringing functional impairment. Finally, it is known that the early mobilization in these cases helps in the condition maintenance of the member and prevents complications. ${ }^{(29)}$

According to the results of this study, the established physiotherapy intervention protocol contributed to the elimination of pain and increased wrist range of motion. It is believed that such benefits were achieved through the set of selected techniques.

\section{CONCLUSION}

The proposed treatment protocol was effective in seven sessions, allowing the reduction of pain and increased wrist range of motion in the patient. Once the protocol allowed no pain at the end of the treatment, and complete recovery of motion.

\section{AUTHOR'S CONTRIBUTION}

MDG and TBM: Design and development (provided the idea for research or article and created the hypothesis); MDG: methodological design (planning methods to generate the results); GMS and LS: Supervision (responsible for organizing and execution of the project and writing of the manuscript); MDG and TBM: Collection and processing of data (responsible for experiments, patients and organization of data); MDG: Analysis / interpretation (responsible for statistical analysis, evaluation and presentation of results); CFS: Literature survey (participated in the bibliographical research and articles survey); MDG, TBM, CFS, GMM: Wording (responsible for writing a substantive part of the manuscript); MDG, TBM, CFS, GMM and LS: Critical revision (responsible for reviewing the intellectual content of the manuscript before final submission).

\section{CONFLICTS OF INTEREST}

The author(s) declare that they have no competing interests.

\section{REFERENCES}

1. Moura RN, Santos FC, Drumeier M, Santos LM, Ramas LR. Quedas em idosos: fatores de risco associados. Gerontologia. 1999;7(2):15-21.

2. Perracini MR, Luiz RR. Fatores associados a quedas em uma coorte de idosos residentes na comunidade. Rev Saúde Pública. 2002.36(6):709-16.

3. Del D, Giovâni F, Danielle LA. Quedas e fraturas entre residentes de instituições de longa permanência para idosos. Revista Brasileira de Epidemiologia. 2013.16(1):68-76.

4. Fabrício SCC, Rosalina A, Partezani R, Moacyr LCJ. Causas e consequências de quedas de idosos atendidos em hospital público. Rev Saúde Pública. 2004.38(1):93-9.

5. Hamra A, Marcelo BR, Omar FM. Correlação entre fratura por queda em idosos e uso prévio de medicamentos. Acta Ortop Bras. 2007.15(3):143-5.

6. Barbosa PSH, Luci FT, Robert BC. Reabilitação das fraturas do rádio distal. Acta Ortopédica Brasileira. 2009.17(3):182-186.

7. Belloti JC, dos Santos JBG, Erazo JP, Iani LJ, Tamaoki MJS, de Moraes VY, et al. Um novo método de classificação para as fraturas da extremidade distal do rádio-a classificação IDEAL. Revista Brasileira de Ortopedia. 2013.48(1):36-40.

8. Albertoni WM, Paula EJL, Toledo LFQ, Giostri G, Freitas A. Fraturas instáveis da extremidade distal do rádio: estudo multicêntrico. Rev Bras Ortop. 2002.37(10):436-44.

9. Aquino CF, Viana SO, Fonseca ST. Comportamento biomecânico e resposta dos tecidos biológicos ao estresse e à imobilização. Fisioterapia em Movimento. 2005.18(2):35-43.

10. Reis FB, Corvello MC, Françoso RM, Faloppa F, Masiero D. Terapia ocupacional no tratamento das fraturas do terço distal do rádio. Folha méd. 1990.100(1/2):15-8.

11. Appell HJ. Muscular atrophy following immobilization. Sports Med. 1990;7:42-58.

12. Durigan JLQ, Cancelliero KM, Dias CNK, Silva CA, Guirro RRJ, Polacow MLO. Efeitos da imobilização articular aguda nos músculos do membro posterior de ratos: análise metabólica e morfométrica. Fisioterapia e Pesquisa. 2006.13(2):31-36.

13. Almeida AL, Jenny $T$, Costa VSF. Reabilitação fisioterapêutica ambulatorial pós fratura distal de rádio: proposta de protocolo em estudo de caso. Universitas: Ciências da Saúde. 2014.11(2):121-127.

14. Kay S, Margaret M, Kathy S. An advice and exercise program has some benefits over natural recovery after distal radius fracture: a randomised trial. Australian Journal of Physiotherapy. 2008.54(4):253-259.

15. Bruder A, Taylor NF, Dodd KJ, Shields N. Exercise reduces impairment and improves activity in people after some upper limb fractures: a systematic review. Journal of physiotherapy. 2011.57(2):71-82.

16. Michlovitz SL, LaStayo PC, Alzner S, Watson E. Distal radius fractures: therapy practice patterns. Journal of Hand Therapy. 2001.14(4):249-257.

17. Marques AP. Manual de goniometria. 2a ed. São Paulo: Manole; 2003.

18. Edmond SL. Manipulação e mobilização: técnicas para membros e coluna. São Paulo: Manole; 2000. 289 p.

19. Kisner C, Colby LA. Exercícios terapêuticos: fundamentos e técnicas. Manole; 2009.

20. Yeng LT, Helena HSK, Manoel JT. Síndrome dolorosa miofascial. Jornal Brasileiro de Oclusão, ATM \& Dor Orofacial. 2010.3(9).

21. Engles M, Donatelli RA, Wooden MJ. Tissue response. Orthopedic Physical Therapy. 2nd ed. New York: Churchill Livingstone; 1994.

22. Fernandes GVB, Fernandes WVB, Macedo CSG, Zeferino TV. Efeito da terapia manual na dor e mobilidade lombar de atletas com lombalgia. Ter. Man. 2009.7(31):181-185.

23. Silva RBX, Afonso SIS. Fisioterapia manual na síndrome dolorosa miofascial (SDM). Ter. Man. 2003.2(2):74-77. 
24. Ferrel BR. Patient education and nondrug interventions. Pain in the Elderly, IASP Press, Seattle. 1996:35-44.

25. Rosa AS, Padilha RF, Carvalho PTC, Missini CC. Estudo comparativo entre três formas de alongamento: ativo, passivo e facilitação neuroproprioceptiva. Ter Man. 2006.4(16):97-101.

26. Rosario JL, Marques AP, Maluf AS. Aspectos clínicos do alongamento: uma revisão de literatura. Braz. J. Phys. Ther. 2004.8(1):83-88.
27. O’Sullivan SB, Schmitz TJ. Fisioterapia: avaliação e tratamento. 5ạ ed. Manole: São Paulo; 2010.

28. Artioli DP. O tempo de imobilização pós fraturas/cirurgias e seus efeitos na reabilitação. UNILUS Ensino e Pesquisa. 2013.9(17):33-34.

29. Artioli DP, Gualberto HD, de Freitas DG, Bertolini GRF. Tratamento Fisioterapêutico na Síndrome Complexa de Dor Regional Tipo I: relato de caso. Rev. Soc. Bras. Clín Méd. 2011.9(1). 